\title{
First Record of Synalpheus africanus Crosnier \& Forest, 1965 (Caridea, Alpheidae) in the Egyptian Mediterranean Coast
}

\author{
Khaled M. Abdelsalam ${ }^{1}$ and Rasha Hamdy ${ }^{2}$ \\ ${ }^{1}$ National Institute of Oceanography and Fisheries and ${ }^{2}$ Oceanography Department, Faculty of \\ Science, Alexandria University, Alexandria, Egypt \\ Kh.abdelsalam@gmail.com
}

\begin{abstract}
The snapping shrimp Synalpheus africanus Crosnier \& Forest, 1965 is recorded for the first time in the Egyptian Mediterranean coast. During August and September 2018, specimens were accidentally collected from the associated fouling communities of the Eastern Harbor of Alexandria city, Egypt. It is the second species of genus Synalpheus Spence Bate, 1888 to be recorded in the Egyptian Mediterranean waters. A brief re-description with illustrative photos, distribution, and remarks for discrimination from other recorded alpheid shrimps are provided.

Keywords: Alpheidae; Synalpheus africanus; systematic; first record; Alexandria; Egypt.
\end{abstract}

\section{Introduction}

Alpheid shrimps are a profoundly variable taxon of crustacean decapod, including more than 600 species disseminated in 47 genera (De Grave and Fransen 2011). Members of family Alpheidae (snapping shrimps) are characterized by: the first pair of pereiopods is extremely uneven and such asymmetry begins in the juvenile stage (Young et al., 1994). The major chela of this appendage is exceptionally well developed, with constant and movable fingers of indeed strange morphology (tooth-cavity system). The chela creates a powerful snapping sound which is a standout amongst the most capable heard sounds in the environments where these creatures live (Versluis et al., 2000; Anker et al., 2006). This cheliped is utilized to catch preys and in agonistic interactions (Nolan and Salmon 1970).

Efficient snapping claws are only developed within family Alpheidae (Anker et al., 2006), which incorporates the dominant genera of Alpheus Fabricius, 1798; Metalpheus Coutière, 1908; Pomagnathus Chace, 1937; Racilius Paul'son, 1875 and Synalpheus Spence Bate, 1888 constitute about $75 \%$ of alpheid species. The snapping claw encouraged the broad radiation experienced by these shrimps (Anker et al., 2006). The minor chela has slim fingers, which are not adjusted for sound generation, but are frequently utilized for nutrition, and burrowing (Govind et al., 1988).

Alpheus Fabricius, 1798 is the most diverse genus of family alpheidae, and represented by more than 300 described species (De Grave and Fransen 2011; Almeida et al., 2014; Bracken-Grissom and Felder 2014; Anker et al., 2015). Meanwhile, Synalpheus Spence Bate, 1888 is the second-diverse genus of the family (Anker et al., 2012), with more than 250 species and subspecies (WoRMS, 2018). Members of genus Synalpheus are important components of coral reef and bottom fauna communities in all tropical and subtropical seas 
(Dardeau, 1984). In the Egyptian Mediterranean waters, genus Synalpheus was represented by only one species; $S$. gambarelloides (known as S. laevimanus) in the coastal water of Alexandria (Balss, 1936). While it is known from the entire Mediterranean Sea (Holthuis and Gottlieb 1958).

According to Crosnier \& Forest (1965, 1966), Synalpheus africanus has been collected from the eastern Atlantic, the Cape Verde Islands, near Biafra Bay, Guinea (Conakry), and the islands of São Tomé, Principe and Annobon. In the Mediterranean Sea, this species has been recorded from different areas: Israel (Lewinsohn and Holthuis 1964); Morocco's coasts (Lagardère, 1971); Greece (Koukouras and Kattoulas 1974); Alboran Sea and southern Spain (García Raso, 1988; García Raso and Fernández Muñoz 1988); and the Italian waters (Bacci et al., 2010). However, it was included in the inventory of decapod crustaceans in the north-eastern Atlantic, the Mediterranean and adjacent inland waters north of $25^{\circ} \mathrm{N}$ (d'Udekem d'Acoz, 1999), and registered also from the Canary Islands (González-Pérez, 1995; Quiles et al., 2001).

The present study aims to document the first record of the tropical East Atlantic Synalpheus africanus Crosnier \& Forest, 1965 which was collected accidentally with fouling communities from the Egyptian Mediterranean waters. A brief re-description with illustrative photos, distribution, and remarks for discrimination from other recorded alpheid shrimps are given.

\section{Material and Methods}

During August and September 2018, specimens of Synalpheus africanus Crosnier \& Forest, 1965 were accidentally sampled while collecting fouling samples from the hard substrates in front of (Building of Oceanography department, Alexandria
University) in the Eastern Harbor of Alexandria city, Egypt (Fig. 1).

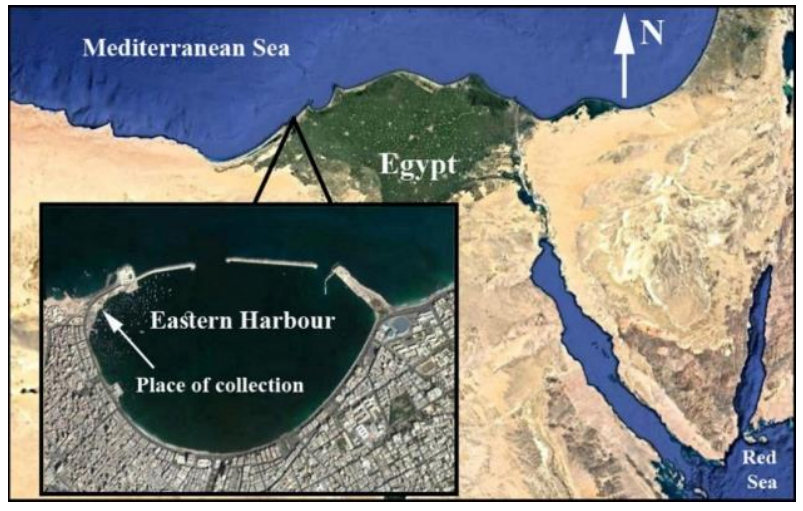

Fig. 1. The Eastern Harbor of Alexandria, Egypt, showing the collection site.

Specimens were sorted out and then preserved in $70 \%$ ethanol, and deposited in the Collection of Taxonomy \& Biodiversity of Aquatic Biota (TBAB) laboratory, National Institute of Oceanography and Fisheries, Alexandria branch, Egypt; and Oceanography Department, Faculty of Science, Alexandria University, Egypt. Later, specimens were examined carefully to identify the species using relevant scientific publications such as (Lewinsohn and Holthuis 1964; Crosnier and Forest 1965, 1966; Anker et al., 2012).

Specimens were studied using stereozoom microscopes (Models Optika SZM-2 \& Novex P-20). Length measurements of individuals were made to the closest $0.01 \mathrm{~mm}$ using an advanced digital caliper. Microphotographs were made under a light microscope with a mounted Nikon digital camera (Model D3200).

The carapace length (CL) was measured in $\mathrm{mm}$ along a mid-dorsal line from the tip of the rostrum to the posterior margin of the carapace.

\section{Results}

\subsection{Systematic Account}

Family: Alpheidae Rafinesque, 1815 
Genus: Synalpheus Spence Bate, 1888

Synalpheus africanus Crosnier \& Forest, 1965

Fig. 2-6

\subsection{Materials Examined}

Only three samples were collected, one ovigorous female, $\mathrm{CL}=8.33 \mathrm{~mm}$; two males with $\mathrm{CL}=8.58$ and $7.15 \mathrm{~mm}$.

\subsection{Synonymized Names}

Synalpheus hululensis africanus Crosnier \& Forest, 1965: 607, Fig. 2; Crosnier \& Forest, 1966: 292, Fig. 29a-g; Lagardère, 1971: 82, Fig. 159-167; García Raso and Fernández Muñoz, 1988: 306; González Pérez, 1995: 77.

Synalpheus tumidomanus africanus d'Udekem d'Acoz, 1999: 107; Quiles et al., 2001: 10; Bacci et al., 2010: 821.

Synalpheus hululensis - Lewinsohn and Holthuis, 1964: 49, Fig. 2a-h; Koukouras and Kattoulas, 1974: 374; García Raso, 1988: 254, 257 (not S. hululensis Coutière, 1908).

\subsection{Description}

Synalpheus africanus Crosnier \& Forest, 1965 is a small snapping shrimp (Fig. 2).

\section{- Carapace}

Rostrum slender reaching at least the distal third of the first article of the antennual peduncle, and inserting in the middle of a depression for separating the two acute orbital spines (Fig. 3C). The pterygostomial angle of the carapace with an acute tooth (Fig. 3B). Stylocerite, triangular and very acute, exceeding the middle second article of the antennual peduncle. The external spine of basicerite, acute, twice as long as the internal one, clearly exceeding the anterior extremity of the first antennual peduncle, while the distal tooth of scaphocerite exceeding the antennual peduncle (Fig. 3C).

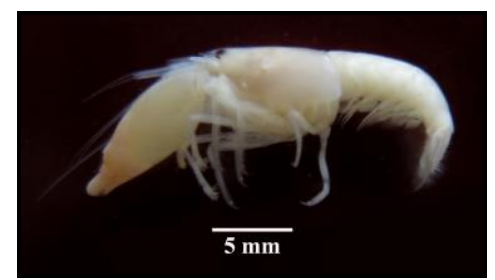

Fig 2. Whole mount of Synalpheus africanus Crosnier \& Forest, 1965.

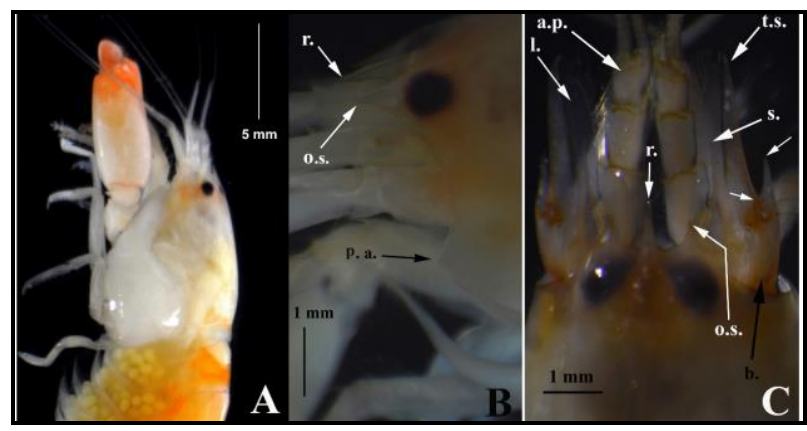

Fig 3. Synalpheus africanus. A. Ovigorous female, Lateral view. B. Anterior carapace, lateral view. C. Anterior carapace of male specimen, dorsal view. a.p., antennular peduncle; b. basicerite; l., lamella of scaphocerite; o.s., orbital spine; p.a., pterygostomian angle; r., rostrum; s., stylocerite; t.s., tooth of scaphocerite. Arrows indicate spines of basicerite.

\section{- Thoracic legs (Pereiopods)}

For the first pereiopods, forceps of the major cheliped with a maximum height nearly at its mid length, and 2.5 to 3 times longer than high (Fig. 4A). The length of the fingers slightly greater than half that of the palmar region; the upper edge of the latter carrying one tooth distally, short, broad, flattened, very blunt peak, sometimes reduced to a tuber. The merus upper edge armed with a distal spiny tooth, tip slightly curved downward. Forceps of the minor cheliped with about 2.8 times longer than high; fingers a little shorter than the palm (Fig. 4B). The second pereiopods with equal length, forceps with slightly longer fingers than the palmar region; its length slightly shorter than half that of carpus; carpus with five segments, first segment about as long as sum of the following distal four segments (Fig. 5A). Constant finger supplied with more bunches of bristles than the movable one. 


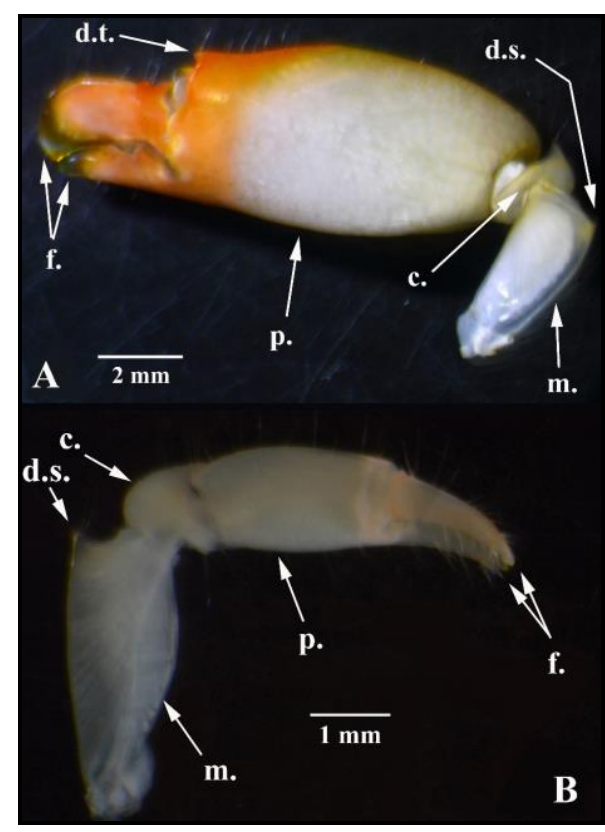

Fig. 4. Synalpheus africanus. First pereiopods, A. Major cheliped, lateral view. B. Minor cheliped, lateral view. c., carpus; d. s., distal spine; d.t., distal tooth; f., fingers; m., merus; p., palm.

In the next three pairs of pereiopods, the dactyli with a biunguiculate end; the ventral unguis shorter, more strongly curved than the dorsal one (terminal nail). The third thoracic paws (Fig. 5B) with a dactyli, four times shorter than the propodus; the latter armed on its lower edge, carrying 9 spiniform bristles, the two distals of which linked. The carpus, with half the length of propodus, bearing a spine distally on its lower edge. Length of merus equals about four times its height, and nearly equivalent to seven sixths of the propodus. The fifth pereiopods with a merus equals to two-thirds of that of the third legs and of substantially the same length as the propodus; at lower level, the latter bearing transverse rows of bristles on its distal twothirds (Fig. 5C).

\section{- Abdomen}

In both sexes, the pleurons of the second abdominal segment largely rounded and those of the sixth forming a slightly acute, bluntpointed angle. In males, the first segment of the pleurons with strong, acute tooth, directed backwards and downwards (Fig. 6A); the lower edge of the third and fifth segment of the pleurons, almost straight, forming an obtuse angle with the supero-posterior edge, meanwhile the lower edge of the fourth segment meeting with the supero-posterior edge at a right angle. Male pleopods without "appendix interna" or "appendix masculina" (Fig. 6B); those of the females with an "appendix interna" on the second to fifth pair of pleopods (Fig. 6C).

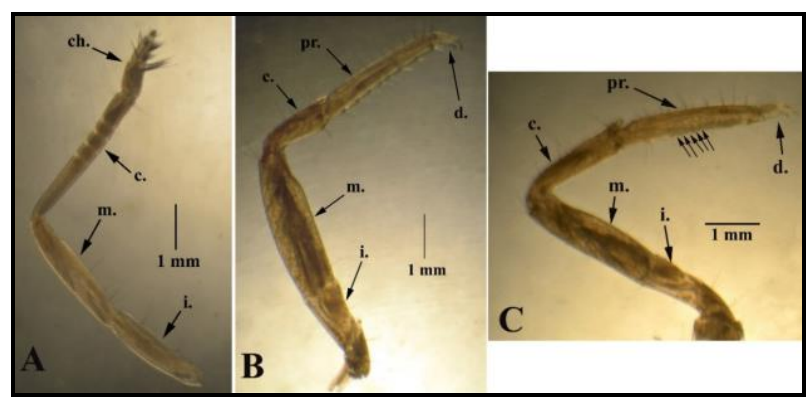

Fig. 5. Synalpheus africanus. A. Second pereiopod, lateral view. B. Third pereiopod, lateral view. C. Fifth pereiopod, lateral view. c., carpus; ch., chela; d., dactylus; i., ischium; m., merus; pr., propodus. Arrows indicate the rows of bristles.

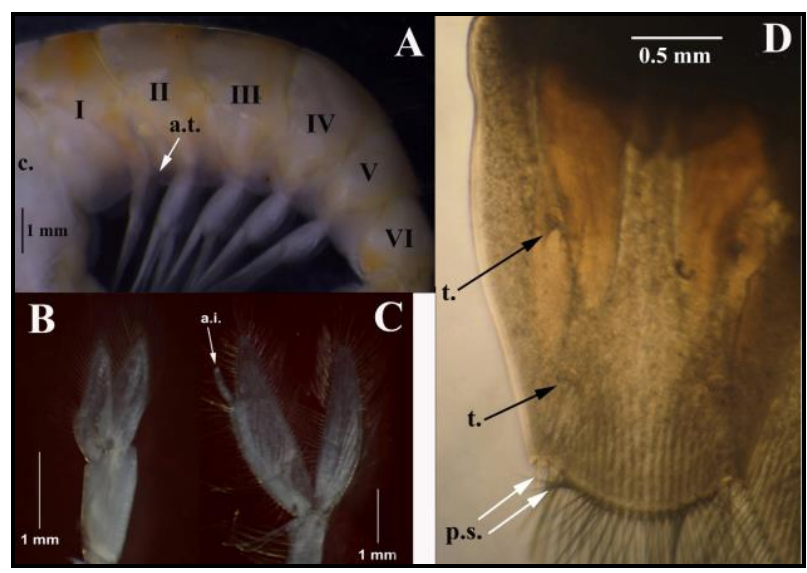

Fig. 6. Synalpheus africanus. A. Male abdomenal segments, lateral view. B. Male second pleopod. C. Female second pleopod. D. Telson, dorsal view. a.i., appendix interna; a.t., acute tooth; c., carapace; p.s., posterolateral spines; t., thorn.

\section{- Telson}

The telson with very slightly concave lateral edges in their posterior half and a 
convex posterior margin; its dorsal surface bearing two pairs of thorns, one inserted towards its middle and the other at the level of the posterior quarter; with two pairs of posterolateral spines (Fig. 6D).

\subsection{Distribution and Life Habits}

Synalpheus africanus is a tropical species distributed in Eastern Atlantic: Mediterranean Sea: from Gibraltar to Israel; Morocco; Cape Verde; Gulf of Guinea: tropical Gulf of Guinea northwards to the warm-temperate waters around the Canary Islands, São Tomé and Principe, Annobón (Crosnier and Forest, 1966; d'Udekem d'Acoz, 1999; Quiles et al., 2001; Bacci et al., 2010; Anker et al., 2012). It is clear that this species is distributed into the Mediterranean Sea through the Strait of Gibraltar. The AtlanticMediterranean connection through the Strait of Gibraltar is a particularly important area for decapod larval dispersal (Pires et al., 2018).

Mainly free snapping shrimp living in crevices of rocks and coralline algae, sometimes among Antipathes sp. in Cape Verde or Mesophyllum lichenoides in southern Spain (García Raso and Fernández Muñoz, 1988) or Dendrophyllia cornigera in Israel (Anker et al., 2012).

\subsection{Remarks}

Regarding the alpheid shrimps of the Egyptian Mediterranean Sea, Balss (1927) recorded Alpheus edwardsii (Audouin, 1827) as (A. audouini) from Port Said. Meanwhile in (1936) he recorded one species of genus Athanas, three species of genus Alpheus, and one species of genus Synalpheus in the fishery grounds near Alexandria. The list has comprised Athanas nitescens (Leach, 1813), Alpheus glaber (Olivi, 1792) [incorrectly named as A. ruber], A. dentipes Guérin, 1832, A. lobidens De Haan, 1849 as (A. crassimanus Heller, 1862), and Synalpheus gambarelloides
(Nardo, 1847) as [S. laevimanus (Heller, 1862)].

Other records of the eastern Mediterranean Sea have included Alpheus inopinatus Holthuis and Gottlieb,1958, A. macrocheles (Hailstone, 1835), A. rapacida De Man, 1908 and A. migrans Lewinsohn and Holthuis, 1978 from Israel (Holthuis and Gottlieb, 1958; Lewinsohn and Holthuis, 1964; Lewinsohn and Galil, 1982). Alpheus macrocheles was first recorded in the eastern Mediterranean Sea by Adensamer (1898) from Sporades, Greece and later it was recorded by (Koukouras and Kattoulas, 1974) from Evvoia.

On the Turkish Coasts, Bakir et al. (2014) recorded eight species: A. dentipes, $A$. edwardsii, A. glaber, A. inopinatus, $A$. lobidens, A. macrocheles, A. migrans and $A$. rapacida. Alpheus lobidens was also found in Lattakia area, Syria (Hasan et al., 2008). However, the present study documents the first record of Synalpheus africanus from the Egyptian Mediterranean waters.

Synalpheus africanus Crosnier and Forest, 1965 is characterized by: Rostrum slender, usually longer than the two orbital spines; stylocerite sharp, not reaching distal margin of second article of antennular peduncle; basicerite of antenna armed with sharp external spine and smaller internal one, external spines clearly exceeding the anterior extremity of the first antennual peduncles; major chela with palm less than twice as long as fingers; and telson tapering posteriorly, with lateral margin slightly concave in posterior half. The present specimens agree well with the description of this species (as S. hululensis africanus) provided by Crosnier and Forest (1965, 1966).

It is well known that genus Synalpheus is more closely related to genus Alpheus. However, members of genus Synalpheus can be distinguished as follows: carapace of genus 
Synalpheus usually with produced pterygostomial angle (rounded and never angular in genus Alpheus) and telson without anal tubercles (usually with anal tubercles in genus Alpheus). Moreover, carpus of the second pereiopods demonstrates an additional difference between the two genera: in genus Synalpheus, first article usually about as long as sum of the distal four articles meanwhile in genus Alpheus, the first article usually shorter than sum of the four following articles (Banner and Banner, 1975).

On the other hand, genus Athanas can be discriminated from the two recorded genera of the Egyptian Mediterranean waters (Alpheus and Synalpheus) by the following criteria: rostrum long, well developed; supra-, extraand infracorneal spines usually present with varying degrees of development; corneas of eyes exposed anteriorly and largely dorsally and laterally. As well as, it is always without the cylinder and the plunger characteristic of genus Alpheus (Banner and Banner, 1973) (i.e. major chela of genus Alpheus is cylindrical, with dactylus plunger of the claw which usually bears stamen-shaped sensillae on its distal end).

Despite the fact that the two species of genus Synalpheus of the Egyptian Mediterranean waters (the previously recorded $S$. gambarelloides and the newly recorded $S$. africanus) are similar, they can be easily distinguished by: the orbital spines are strongly pointed in S. africanus (Fig. 3B, C), being blunt in $\mathrm{S}$. gambarelloides; the stylocerite in $S$. africanus extends behind the middle of the second segment of the antennular peduncle (Fig. 3C), while it drops to reach the base of that segment in $S$. gambarelloides; the lamella of the scaphocerite in $S$. africanus is actually well progressed, reaching to somewhere around two thirds of the length of the scaphocerites tooth (Fig. 3C), while in S. gambarelloides, this lamella is reduced to a little flap at the base of the tooth; the antennal peduncle in S. africanus exhibits two prominent acute teeth close to the base of the scaphocerite (the outer tooth is the longest but drops to reach as far as the stylocerite and the inner one is considerably little smaller but well-formed and strongly pointed) (Fig. 3C), meanwhile in $S$. gambarelloides the outer tooth reaches beyond the stylocerite and is clearly pointed, but the inner tooth, is completely missing here; the palm of the large cheliped in S. africanus ends dorsally at most in a blunt lobe or tooth, while in S. gambarelloides it ends in a solid strongly pointed anterior spine. Moreover, the minor first cheliped of $S$. gambarelloides bears a conspicuous tuft of hairs on the upper edge of the dactylus (moving finger); such tuft is not existing in $S$. africanus.

In conclusion, the present study confirms the existence of snapping shrimp Synalpheus africanus Crosnier \& Forest, 1965 for the first time in the Egyptian Mediterranean waters. This finding adds to the biodiversity of fauna in the Egyptian Mediterranean Sea. This species can be distinguished from its congenic sister species ( $S$. gambarelloides) based on the following characteristics: shape of the orbital spines, the length of the stylocerite relative to the antennular peduncle, the development of the lamella of the scaphocerite relative to the length of the tooth, shape and size of teeth of the antennal peduncle, at the base of the scaphocerite, the dorsal shape of the end of the major cheliped and the availability of conspicuous tuft of hairs on the upper edge of the dactylus (moving finger).

\section{References}

Adensamer, T. (1898) Decapoden Gesammelt auf S.M. Schiff Pola in den Jahren 1890-1894. Zoologi-sche Ergebnisse. XI. Berichte der Commission für Erforschung des östlichen Mit- telmeeres. XXII. Denkschr. Akad. Wiss. Wien, 65: 597-628, I text figure.

Almeida, A.O., Terossi, M. and Mantelatto, F.L. (2014) Morphology and DNA analyses reveal a new cryptic 
snapping shrimp of the Alpheus heterochaelis Say, 1818 (Decapoda: Alpheidae) species complex from the western Atlantic. Zoosystema, 36: 53-71.

Anker, A., Ahyong, S. T., Noel, P. Y. and Palmer, A. R. (2006) Morphological phylogeny of alpheid shrimps: parallel preadaptation and the origin of a key morphological innovation, the snapping claw. Evolution, 60: $2507-2528$.

Anker, A., Komai, T. and Marin, I. N. (2015) A new echiuran associated snapping shrimp (Crustacea: Decapoda: Alpheidae) from the Indo-West Pacific. Zootaxa, 3914: 441-455.

Anker, A., Pachelle, P.G., De Grave, S. and Hultgren, K. M. (2012) Taxonomic and biological notes on some Atlantic species of the snapping shrimp genus Synalpheus Spence Bate, 1888 (Decapoda, Alpheidae). Zootaxa, 3598: $1-96$.

Bacci, T., Marusso, V., Trabucco, B. and Magaletti, E. (2010) First record of Synalpheus tumidomanus africanus (Crosnier \& Forest, 1965) (Caridea, Alpheidae) in Italian waters. Crustaceana, 83: 821-827.

Bakir, A. K., Katağan, T., Aker, H.V., Özcan, T., Sezgin, M., Ateş, A.S., Koçak, C. and Kirkim, F. (2014) The marine arthropods of Turkey. Turk. J. Zool., 38(6): 765831.

Balss, H. (1927) Crustacea Decapoda (Natantia und Anoimira) (Cambridge Expedition, 1924), in: Transactions of the Zoological Society, London, Part 2.

Balss, H. (1936) The fishery grounds near Alexandria. VII. Decapoda. Notes and Memoirs of the Fisheries Research Directory of Egypt, 15: 1-67.

Banner, D. M. and Banner, A.H. (1973) The alpheid shrimp of Australia. Part I. The lower genera. Records of the Australian Museum, 28 (15): 291-382.

Banner, D. M. and Banner, A.H. (1975) The alpheid shrimp of Australia. Part II: the genus Synalpheus. Records of the Australian Museum, 29 (12): 267-389.

Bracken-Grissom, H. D. and Felder, D. L. (2014) Provisional revision of American snapping shrimp allied to Alpheus floridanus Kingsley, 1878 (Crustacea: Decapoda: Alpheidae) with notes on A. floridanus africanus. Zootaxa, 3914: 441-455.

Crosnier, A. and Forest, J. (1965) Note préliminaire sur les Alpheidae recuellis par la Calypso dans l'Atlantique Oriental Tropical (Crustacea Decapoda Natantia). Bulletin du Muséum national d'Histoire naturelle, 36 (2): 602-610.

Crosnier, A. and Forest, J. (1966) Résultats Scientifiques des Campagnes de la "Calypso". Fascicule VII. Campagne de la Calypso dans la Golfe de Guinée et aux Iles Principe, São Tomé et Annobon (1956), et campagne aux Iles du Cap Vert (1959) (suite). 19. Crustacés décapodes: Alpheidae. Annales de l'Institut Océanographique, 44: 199-314.
d'Udekem d'Acoz, C. (1999) Inventaire et distribution des crustacés décapodes de l'Atlantique nord-oriental, de la Méditerranée et des eaux continentales adjacentes au nord de $25^{\circ} \mathrm{N}$. Institut d'Ecologie et de Gestion de la Biodiversité, SPN, Muséum national d'Histoire naturelle, Paris, 383 pp.

Dardeau, M. R. (1984) Synalpheus shrimps (Crustacea: Decapoda: Alpheidae) I. The Gambarelloides group, with a description of a new species. Memoirs of the Hourglass Cruises, 7 (II): 1-125.

De Grave, S. and Fransen, C. H. J. M. (2011) Carideorum catalogus: the recent species of the dendrobranchiate, stenopodidean, procarididean and caridean shrimps (Crustacea: Decapoda). Zoologische Mededelingen, 85 (9): 195-589.

García Raso, J. E. and Fernández Muñoz, R. (1988) Estudio de una comunidad de crustáceos decápodos de fondos "coralígenos" del alga calcarea Mesophyllum lichenoides del sur de España. Investigación Pesquera, 51: 301-322.

García Raso, J. E. (1988) Consideraciones generales sobre la taxocenosis de crustáceos decápodos de fondos de concrecionamiento calcáreo superficial del alga Mesophyllum lichenoides (Ellis and Sol.) Lemoine (Corallinacea) del Mar de Alborán. Investigación Pesquera, 52: 245-264.

González-Pérez, J. A. (1995) Catálogo de los crustáceos decápodos de las Islas Canarias. Gambas. Langostas. Cangrejos. Publicaciones Turquesa S. L., Santa Cruz de Teneriffe, $282 \mathrm{pp}$.

Govind, C. K., Wong, A. and Pearce, J. (1988) Experimental induction of claw transformation in snapping shrimps. The Journal of Experimental Zoology, 248: $371-375$.

Hasan, H., Zeini, A. and Noël, P. (2008) The Marine Decapod Crustacea of the Area of Lattakia, Syria. Crustaceana, 81(5): 513-536.

Holthuis, L.B. and Gottlieb, E. (1958) An annotated list of Decapod Crustacea of the Mediterranean coast of Israel, with an appendix listing the Decapoda of the Eastern Mediterranean. Bulletin of the Research Council of Israel, 7B: 1-126, text fig. 1-15, pl. 1 - 3.

Koukouras, A. and Kattoulas, M. (1974) Benthic fauna of the Evvoia coast and Evvoia Gulf. III. Natantia (Crustacea, Decapoda). Scientific Annals of the Faculty of Physics and Mathematics, University of Thessaloniki, 14: 369-382.

Lagardère, J. P. (1971) Les crevettes des côtes du Maroc. Travaux de l'Institut Scientifique Chérifien et de la Faculté des Sciences, Zoologie, 36: 6-140.

Lewinsohn, C. and Galil, B. (1982) Notes on species of Alpheus (Crustacea Decapoda) from the Mediterranean coast of Israel. Quod. Lab. Tecnol. Pesca, 3 (2-5): 207210 . 
Lewinsohn, C. and Holthuis, L.B. (1964) New records of decapod Crustacea from the Mediterranean coast of Israel and the eastern Mediterranean. Zoologische Mededelingen, 40: 45-63.

Lewinsohn, C. and Holthuis, L.B. (1978) On a new species of Alpheus (Crustacea Decapoda, Natantia) from the Eastern Mediterranean. Zool. Meded. Leiden, 53 (7): 7582 , text fig. 1,2 .

Nolan, B. A. and Salmon, M. (1970) The behavior and ecology of snapping shrimp (Crustacea: Alpheus heterochaelis and Alpheus normanni). Forma et Functio, 2: $289-336$.

Pires, R., Pan, M., Catalán, I., Prieto, L., Santos, M., Faria, C., Ferreira, S. and Santos, A. (2018) The AtlanticMediterranean ecological connection: a study on decapod larval communities. Mediterranean Marine Science, 19 (3): $477-490$
Quiles, J.A., Gonzáles, J. A. and Santana, J. I. (2001) Dendrobranchiata y Caridea nuevos o poco conocidos para las islas Canarias (Crustacea, Decapoda). Boletín Instituto Español de Oceanografía, 17: 7-13.

Spence Bate, C. (1888) Report on the Crustacea Macrura collected by the Challenger during the years 1873-76. Report on the Scientific Results of the Voyage of H.M.S. "Challenger" during the years 1873-76, 24, i-xc + 1-942.

Versluis, M., Schmitz, B., von der Heydt, A. and Lohse, D. (2000) How snapping shrimp snap: Through cavitating bubbles. Science, 289: 2114-2117.

WoRMS (2018). Synalpheus Spence Bate, 1888. Accessed at: http://www.marinespecies.org/aphia.php?p=taxdetails\&id $=106982 \&$ allchildren $=1$ on $2018-10-20$.

Young, R. E., Pearce, J. and Govind, C. K. (1994) Establishment and maintenance of claw bilateral asymmetry in snapping shrimps. Journal of Experimental Zoology, 269: 319-326. 


\section{أول تسجيل لسينألفيس أفريكانيس كروسنير وفوريست، 970 (الإربيانات، الروبيان المزمجر) على ساحل البحر المتوسط المصري خالا محمود عبد السلام'، و رشا حمدي'}

' المعهة القومي لعلوم البحار والمصايد، جمهورية مصر العربية، و "قسم علوم البحار، كلية العلوم، جامعة

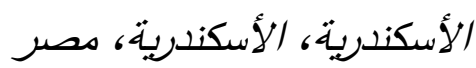

kh.abdelsalam@gmail.com

الستخلص. تم تسجيل الروبيان المزمجر سينألفيس أفريكانيس كروسنير وفوريست، 970 ام

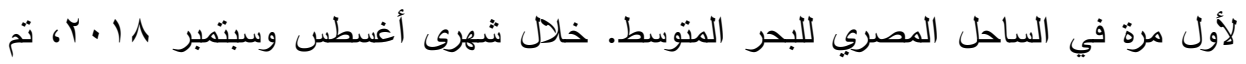
تجميع العينات بالمصادفة من مجتمعات الحشف البحري في الميناء الثرقي لمدينة الأسكندرية،

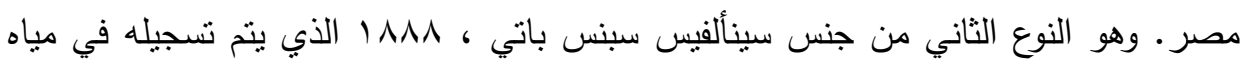
البحر الدنوسط الدصرية. وهناك إعادة وصف موجز لهذا النوع مدعم بصور توضيحية،

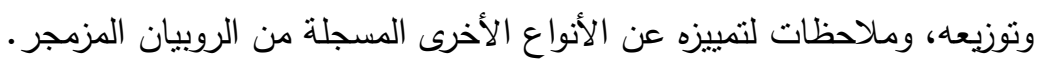
كلمات منتاحية: الروبيان المزمجر، Synalpheus africanus، تصنيف، أول تشجيل،

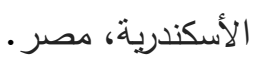


